\title{
Overview of Methods of CuTting Edge Preparation
}

\section{MAREK VOZÁR, BORIS PÄTOPRSTÝ, TOMÁŠ VOPÁT, JOZEF PETERKA}

Abstract: The article deals with various conventional methods used for edge preparation of monolithic solid carbide tools or cutting inserts. Among the most used mechanical methods for modifying cutting edge microgeometry belong the following mechanical processes: drag finishing, micro-grinding, microblasting, brushing and magnetic polishing. Thermal methods of edge preparation are also described: laser machining and electrolytic abrasive edge honing. Advantages and drawbacks of each method are described, as well as parameters influencing the outcome of the process. Choosing the right method of cutting edge preparation along with its proper parameters is vital for achieving desired microgeometry and surface quality of the cutting tool, which results in increasing the tool life.

Key words: milling tools, cutting edge, edge preparation, tool microgeometry, tool wear
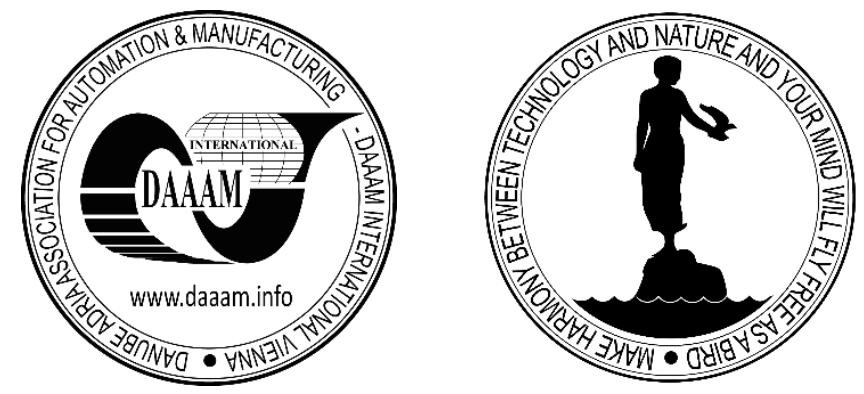

Authors' data: Vozár, M[arek]; Pätoprstý, B[oris]; Vopát T[omáš] \& Peterka, J[ozef], Slovak University of Technology Jána Bottu 2781/25 917 24, Trnava, SK, xvozarm@stuba.skt, boris.patoprsty@stuba.sk, tomas.vopat@stuba.sk

This Publication has to be referred as: Vozar, M[arek]; Patoprsty, B[oris]; Vopat, T[omas] \& Peterka, J[ozef] (2019). Overview of Methods of Cutting Edge Preparation, Chapter 20 in DAAAM International Scientific Book 2019, pp.251-264, B. Katalinic (Ed.), Published by DAAAM International, ISBN 978-3-902734-24-2, ISSN 17269687, Vienna, Austria

DOI: $10.2507 /$ daaam.scibook.2019.20 
Vozar, M.; Patoprsty, B.; Vopat, T. \& Peterka, J.: Overview of Methods of Cutting ...

\section{Introduction}

Tool geometry can be considered from different scales, there is macro-geometry that describes general dimensions of the tool, cutting angles, chip breakers etc., with the order of magnitude higher than $100 \mu \mathrm{m}$.

Then there is meso-geometry that deals with cutting edge radius with the order of magnitude ranging from 1 to $100 \mu \mathrm{m}$. The smallest order of magnitude below $1 \mu \mathrm{m}$ is described as tool's micro-geometry. [1]

The meso- and micro-geometries of the tools have not been thoroughly investigated by the tool manufacturers, mostly due to inaccurate edge preparation methods that do not allow for desired repeatability of the process.

In the following article, currently available methods of mechanical and thermal cutting edge preparation are described. They are categorized according to the various sources of energy that are used to remove material from the cutting edge. [2, 3]

\section{Mechanical edge preparation processes}

Methods of edge preparation that belong in this category use various mechanical means to achieve desired edge radius shape. In figure 1 there are schemes of all the methods described in the article. [4]

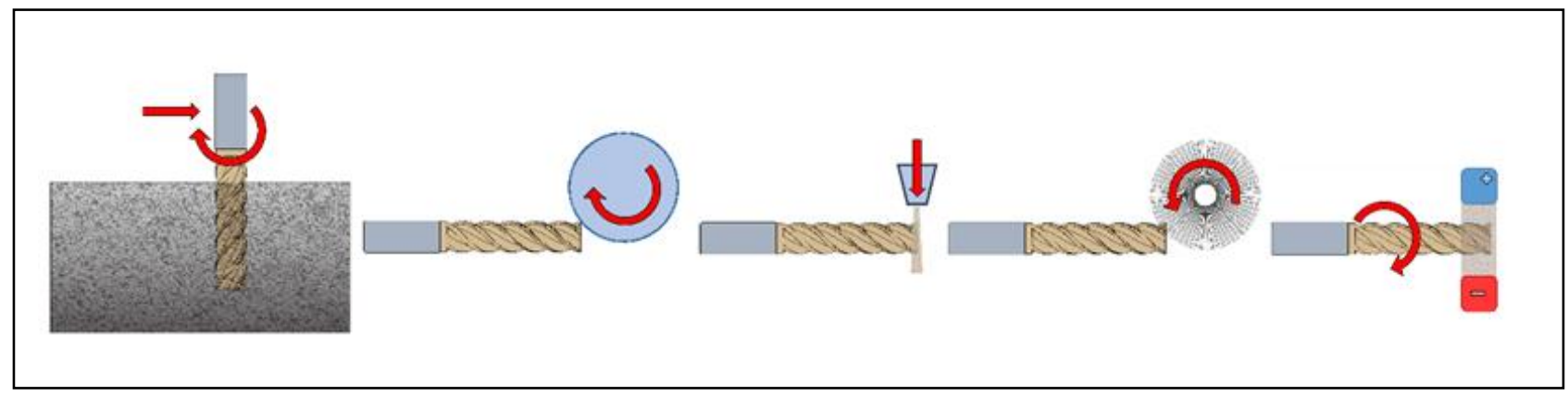

Fig. 1. Mechanical preparation processes [5]

\subsection{Drag Finishing}

This method is usually used for deburring and edge rounding of workpieces, but it has been successfully adapted also for microgeometry modification of carbide tools or inserts.

It is considered as a mass finishing technology, because it can be used for multiple tools at once.

The tools are moving in a container with granulate. The movement consists of both translation and rotation. Most modern drag finishing machines are built on a principle of planetary gears. [6] 
Parameters of the process are following:

- Process media material and size

- Feed rate

- Spindle rotation speed

- Time

- Tool immersion depth [7]

Modifying tool microgeometry using drag finishing has useful advantages, such as short process cycle and relatively low operating costs. Desired results can be accurately controlled by changing the process parameters.

However, carrying out the process without verified parameters can result in overfinishing of the tool surface, which can cause significant erosion of the surface. This has negative effect on both tool wear and coating adhesion. [8]

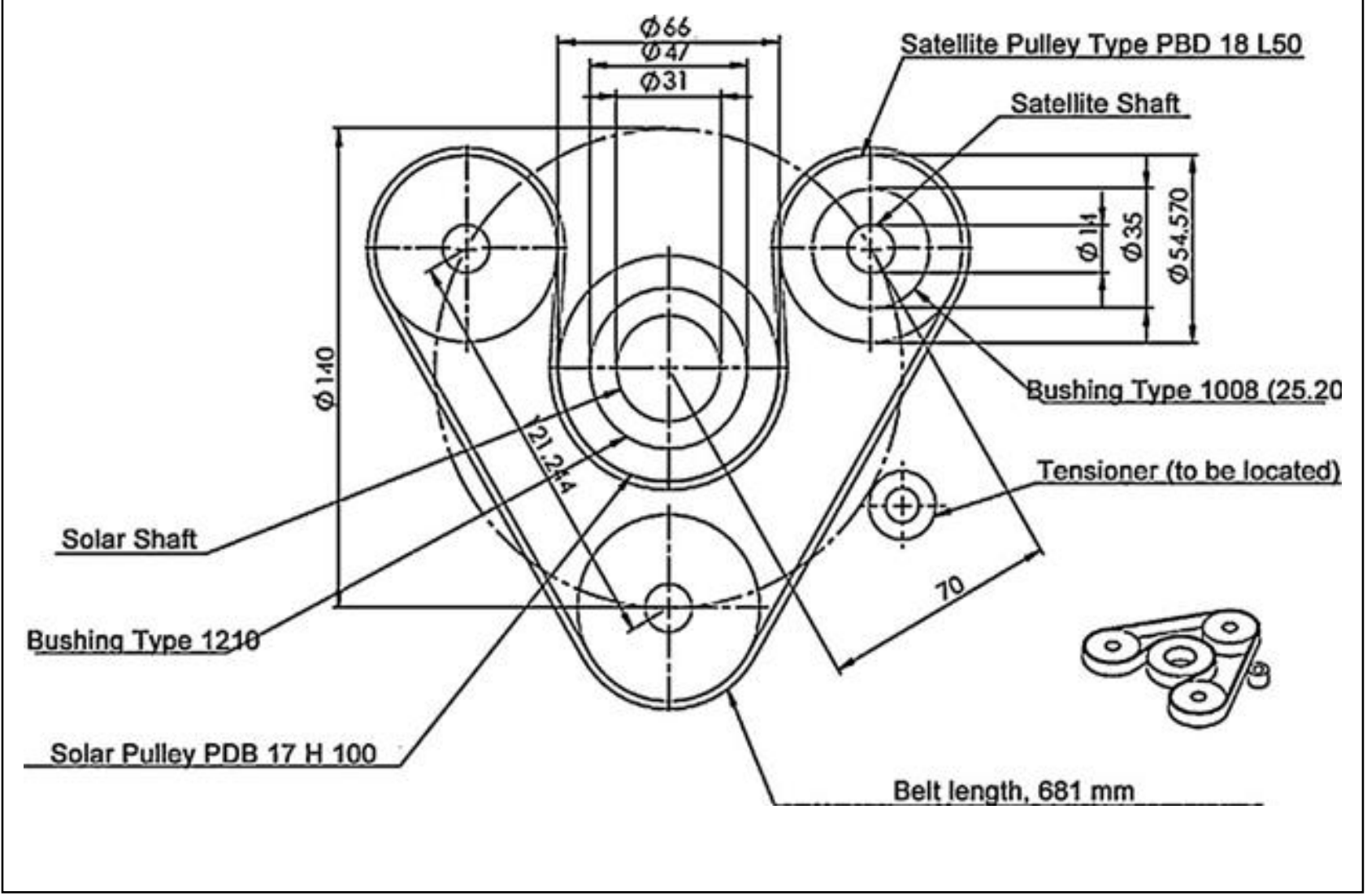

Fig. 2. Scheme of the rotary turntable and satellite stations [8]

Another disadvantage is uneven rounding along the cutting edges, as well as different radius of the cutting edge on the helix and face teeth that can be caused by spindle rotation speed being too high. This has been verified by the experiment results of which are displayed in the figure 3. [9] 


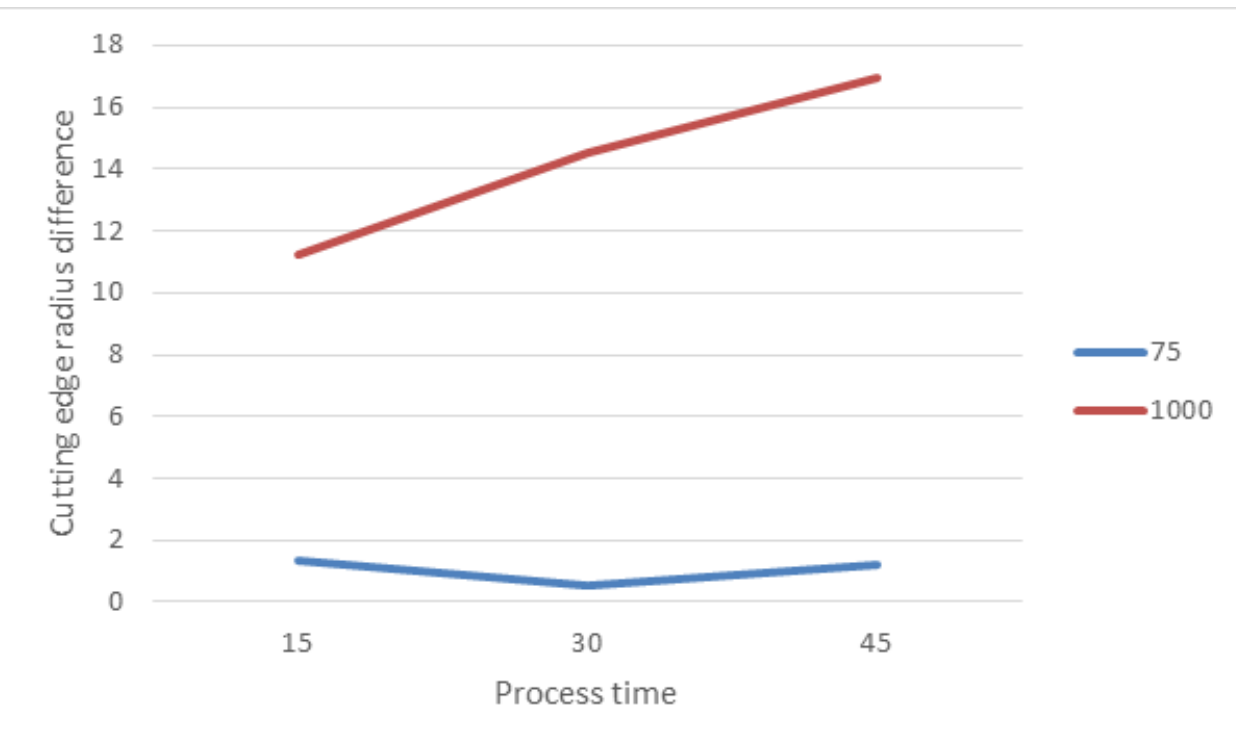

Fig. 3. Differences of cutting edge radius size between the face and helix teeth [10]

\subsubsection{Abrasives for drag finishing}

There are two main groups of finishing media that can be used in the process - ones intended for wet finishing and those for dry finishing. Final surface quality and edge roundness depends on the usage of correct finishing media for the process. Type of the media is chosen based on both the machine used for drag finishing as well as the workpiece type and material. [Gabriel]

For wet finishing, there is water or compound mixed into the solid media. Its purpose is to absorb and carry away particles of excess material removed from the workpiece as well as the small fragments that got chipped off from the finishing media. Use of wet finishing is important for operations with certain sort of workpieces to prevent clogging of the media and maintaining efficiency of the finishing process. [11]

Following types of media materials are used for wet finishing:

- Plastic grinding chips - high surface quality, prevent hardening or damage of finished surface, used for precious and soft metals,

- Ceramic particles - high density and hardness, used for steel alloys,

- Stainless steel strips - for smoothing and compacting of the finished surface of soft materials,

- Zirconium balls - for smoothing and compacting of the finished surface of hard materials,

- Microfinishing sintered ceramics - for very hard materials.[11]

Main use of dry finishing process is for surface polishing. Polishing paste or powder adherent to the finishing medium can be used. Movement of the workpieces in the abrasive creates friction that causes material removal and achieving high surface quality. 
Following types of media materials are used for dry finishing:

- Walnut shell granulate - used for hard materials such as titanium and steel alloys

- Polyethane + Silicon carbide granulate - self sharpening, used for edge rounding of cutting tools

- Plastic chips - dust free operations, used for hollow workpieces,

- Corn granulate - used for fine surface polishing. [11]

Correct type and size of the abrasive media used for drag finishing cutting tools is crucial, because it is one of the key factors influencing the size of achievable cutting edge radius, as well as the process time needed to achieve desired cutting edge radius. [12]

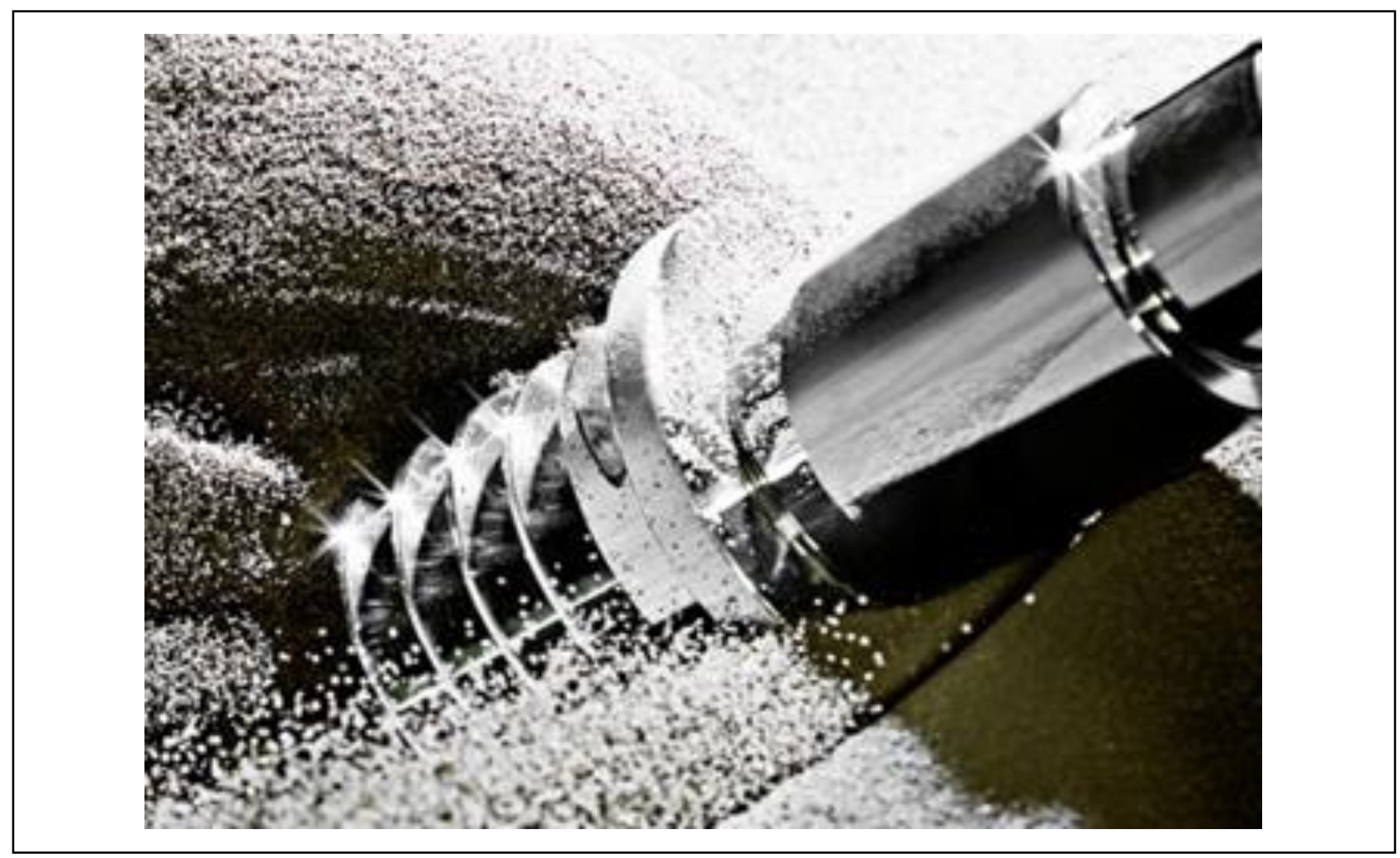

Fig. 4. Drag finishing in a granulate [11]

\subsection{Layout of Manuscript (14 pt, italic)}

Modifying the cutting edge by means of grinding the rake face, edge radii lower than $\mathrm{r}_{\mathrm{n}}<5 \mu \mathrm{m}$ can be achieved. This technology can also be used to achieve specific shape of the cutting edge consisting of multiple chamfers while removing larger volume of the excess material from the cutting edge.

Another advantage of this method is that uniform edge shape can be obtained on the insert perimeter. While for other methods of edge preparation the parameters of the process influence the size of the edge radius, for grinding the edge radius is fixed and changing the process parameters influences only the quality of the end result, not the edge radius size or shape. Therefore the process is more flexible and requires less time to attain the desired cutting edge size and shape. [13] 


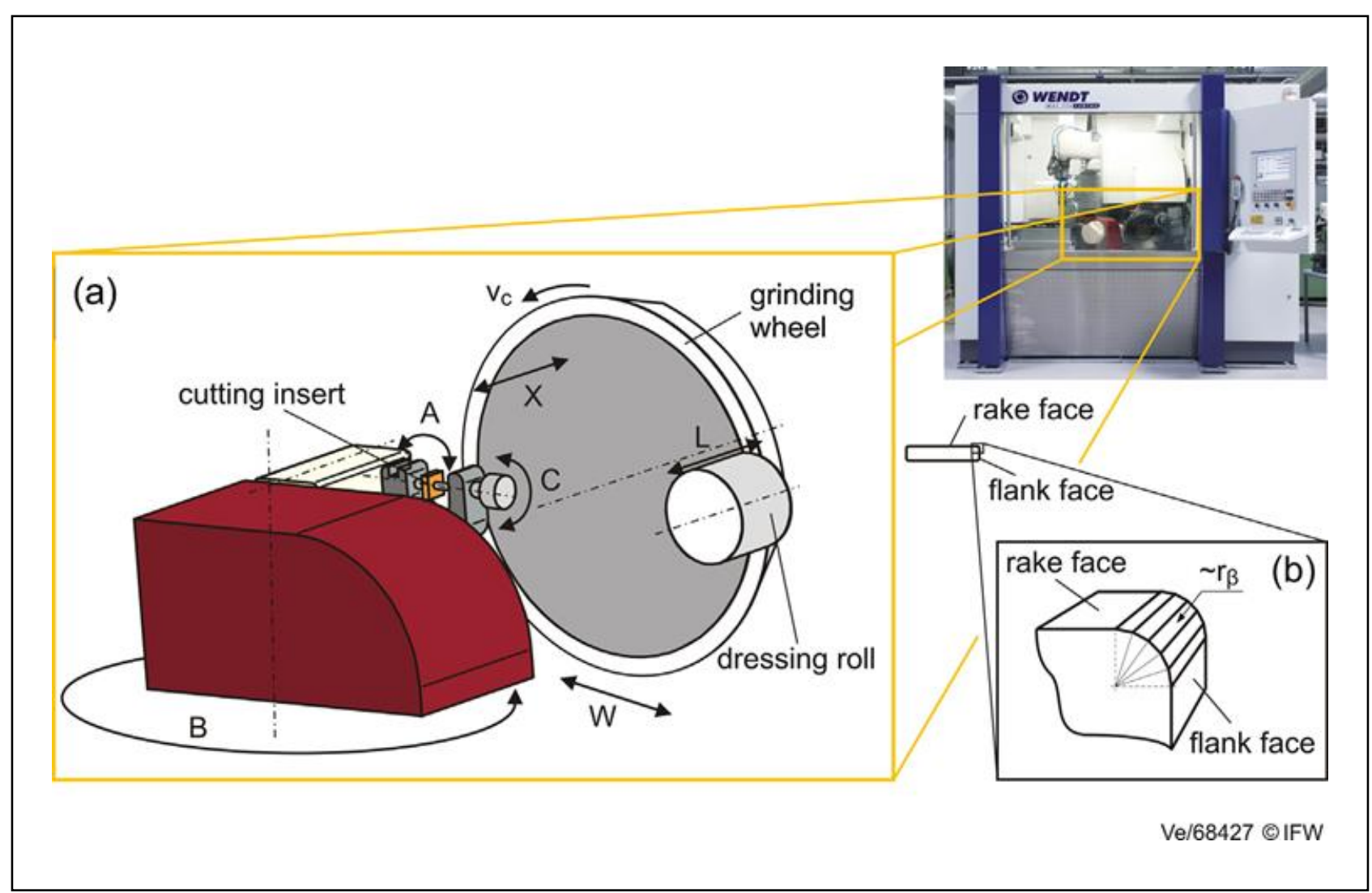

Fig. 5. Customized cutting edge preparation by means of grinding [14]

\subsection{Microblasting}

Process of micro-blasting can be divided into two categories - dry and wet microblasting.

\subsubsection{Dry microblasting}

While dry microblasting is primarily used for modifying of coated surfaces of solid carbide [15], wet microblasting has been successfully applied for the modification of tool microgeometry and surface quality [16]. While wet microblasting process seems like it lacks secure reproductibility, thanks to the number of parameters that can be modified it is one of the methods of edge preparation that offers the most advantages, as it can be precisely controlled.

Parameters:

- Orientation

- Blasting speed

- Fluidity

- Focusing

- Pressure

- Nozzle diameter

- Blasting method (combination of rotation speed and modulation speed).

Nozzle diameter and blasting pressure are the most important ones since they are correlated, and need to be tweaked in order to achieve linear blasting jet. [17] 


\subsubsection{Wet microblasting}

Use of water combined with abrasive suspension offers some important advantages when modifying cutting edges compared to dry blasting processes. Presence of water in the process results in a damping effect, which results in low surface roughness of affected surface. It also helps with accumulation of residual powder on the surface of the tool. $[18,19]$.

Another advantage that water brings to the process is that due to its conductivity, it can help with reducing or even avoiding thermal damage of the workpiece. [20] However, the process is complex, because of the number of variables that affect the outcome of the edge preparation.

Parameters:

- Abrasive media

- Jet mass concentration

- Jet pressure

- Nozzle outlet diameter

- Jet distribution intensity

- Jet expansion angle

- Relative jet inclination angle

- Jet nozzle distance

- Jet feed speed [21]

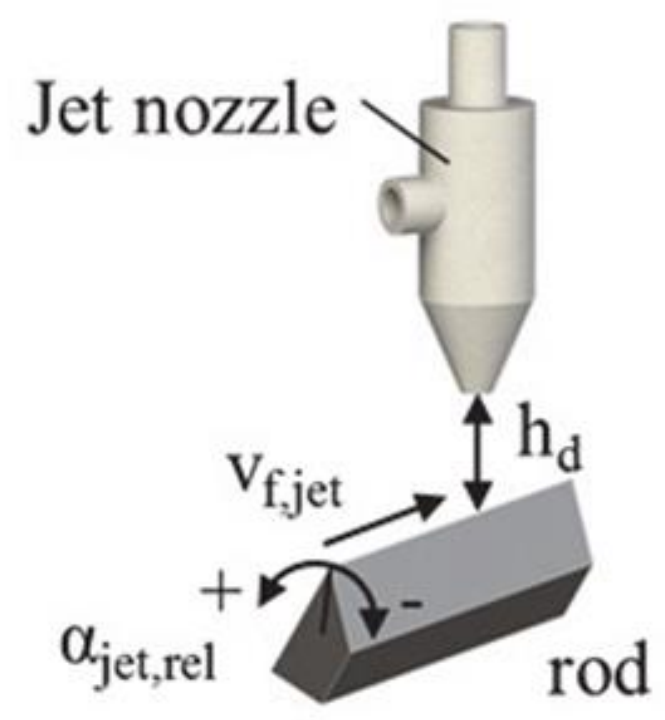

Fig. 6. Water jet machining scheme with selected parameters [21]

Wet sandblasting has also positive impact on the surface quality, resulting in better adhesion of coating on the tool surface which in turn reduces tool wear and increases tool life. [22] 
Vozar, M.; Patoprsty, B.; Vopat, T. \& Peterka, J.: Overview of Methods of Cutting ...

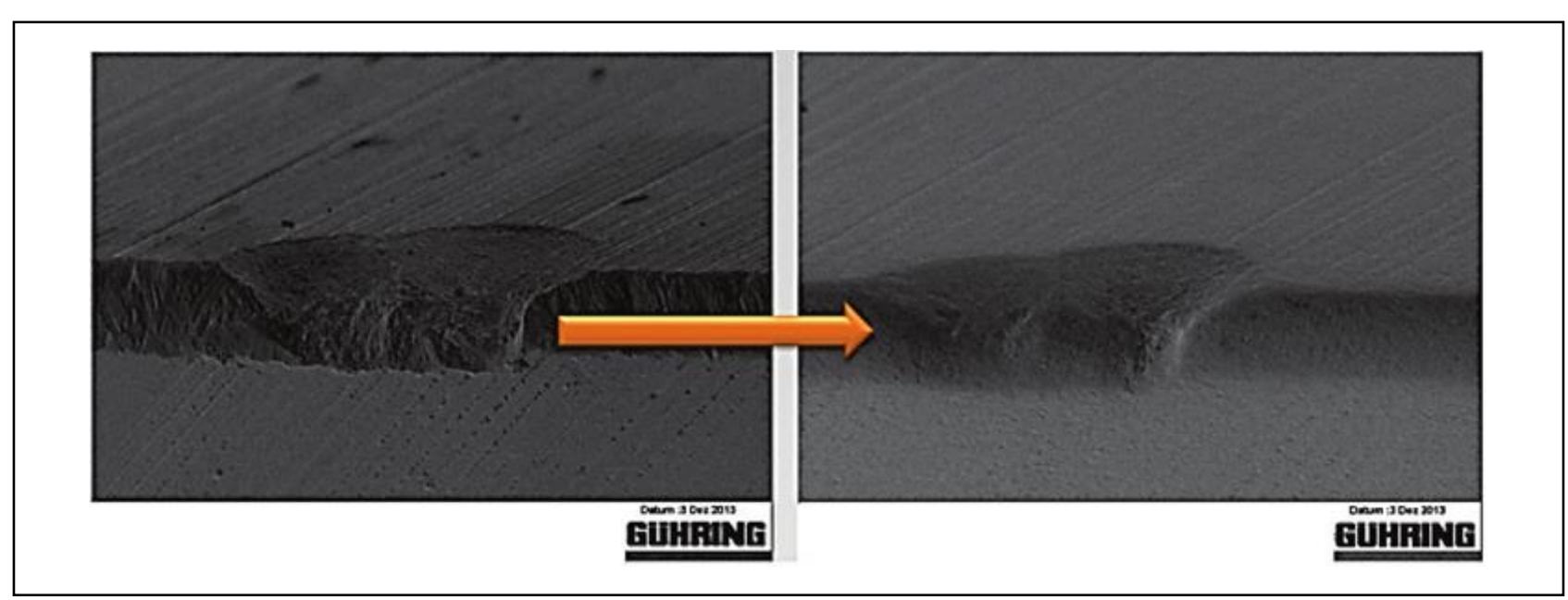

Fig. 7. Water jet machining scheme with selected parameters [21]

\subsection{Brushing}

Process of brushing the tool cutting edge can be carried out by two means - either nylon abrasive filaments (NAF) or steel wire. NAF removes only small volume of the material, so its main effect is achieving good surface quality and deburring. Abrasive media used for this method are silicon carbide and aluminum oxide. Cubic boron nitride or polycrystalline diamond can be used as well. Following are the process parameters:

- brushing time,

- brushing angle,

- cutting speed,

- penetration depth.

Increasing these parameters leads to a higher edge radius. [24]

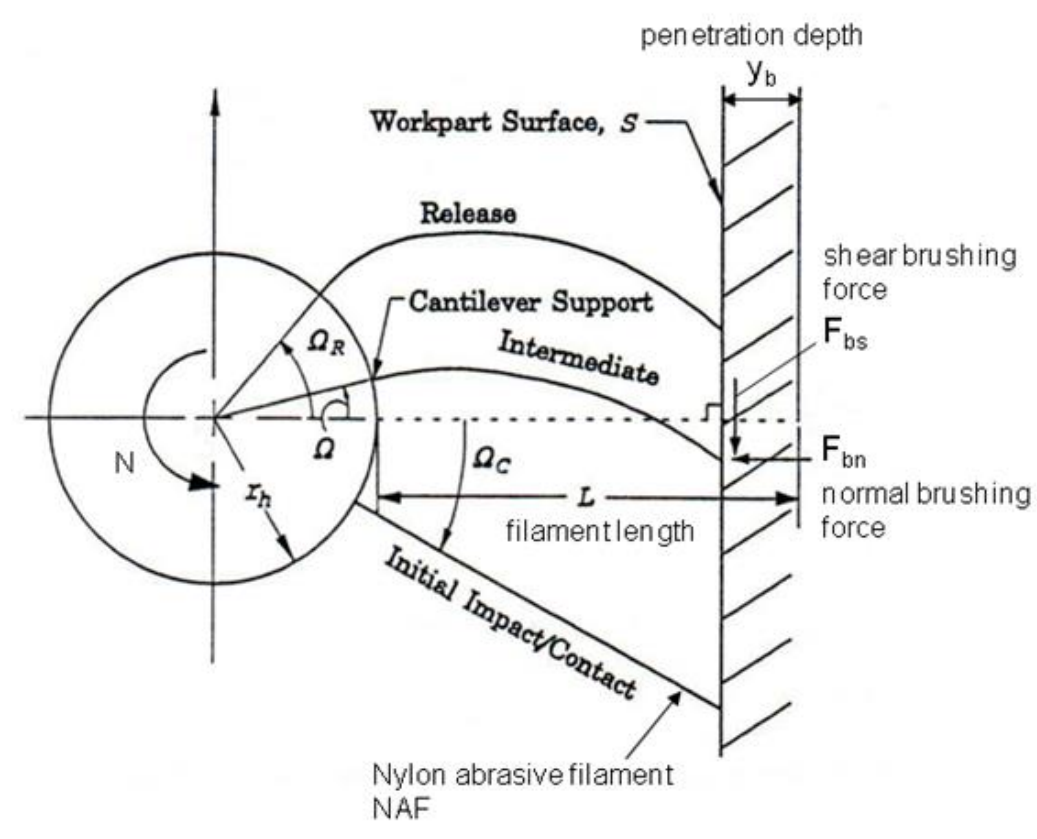

Fig. 8. Principle of brushing with nylon abrasive filaments [5] 


\subsection{Magnetic polishing}

Main purpose of the magnetic polishing process is for deburring and polishing small metal parts, and it has been used for edge preparation of high speed steel tools as well. It can offer some benefits compared to other methods.

Setting up the process is simple, and the machines are relatively cheap. It can be automated to some extent, reducing the time needed for human interaction with the process, and machines usually do not require much power. It is also suitable for use on parts with complicated shapes. [25]

The method has following parameters that need to be tweaked to achieve desired outcome when preparing the cutting edge:

- Polishing material type,

- shot size,

- magnet rotation speed,

- polishing time.

These parameters are also depend on the type and configuration of the machine used. [26]

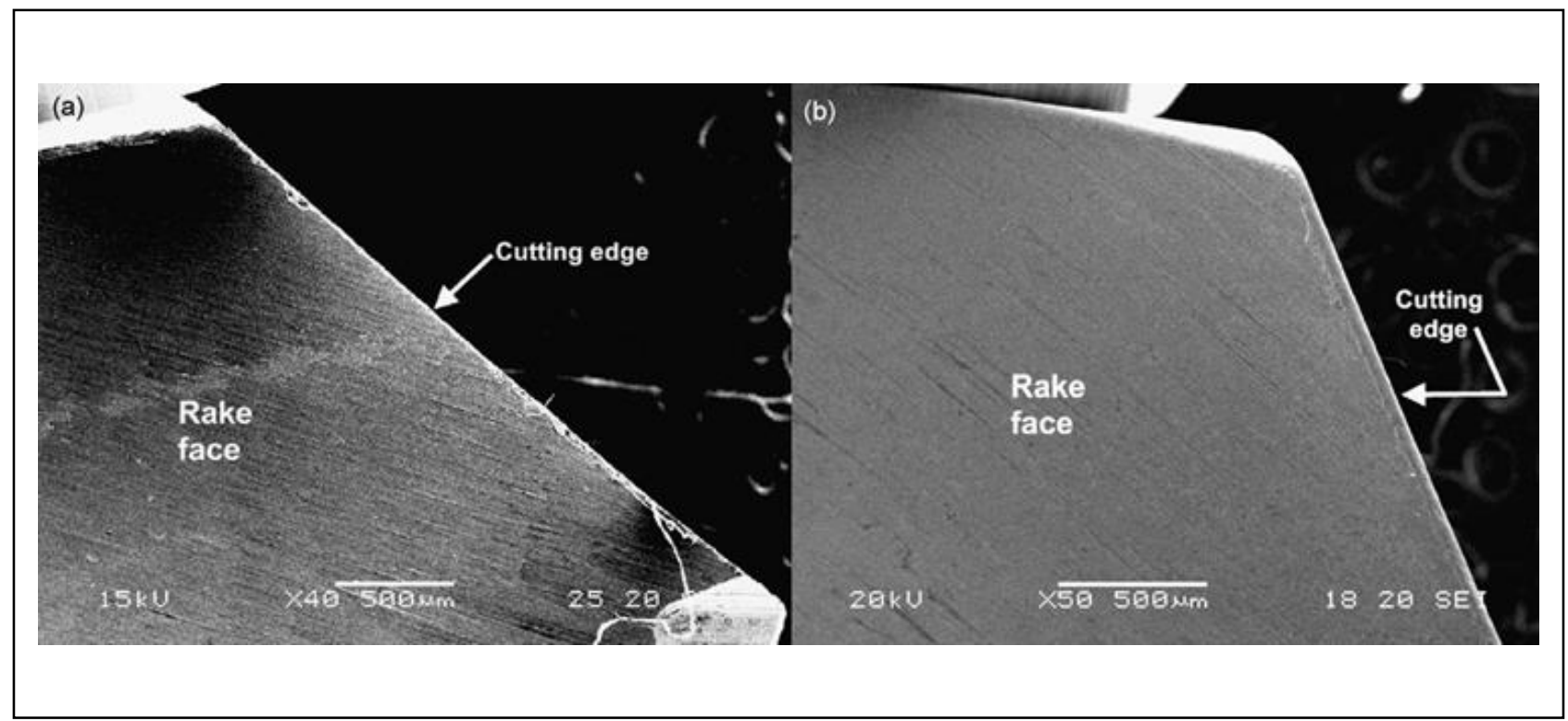

Fig. 9. Cutting edge before (a) and after (b) magnetic polishing [25]

\section{Thermal edge preparation processes}

Methods of edge preparation in this category use various thermal sources of energy to achieve desired edge radius shape. 

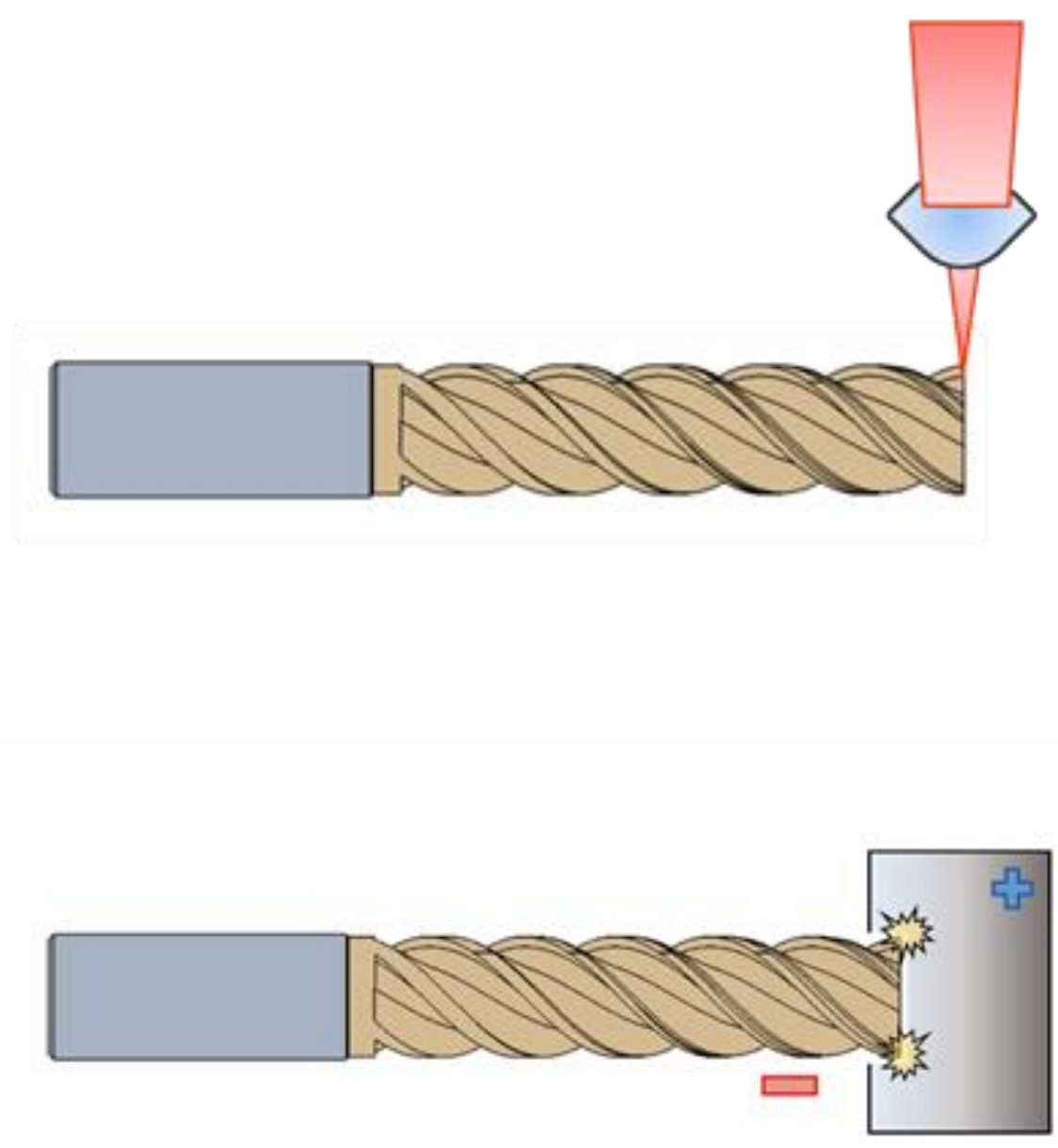

Fig. 10. Cutting edge before (a) and after (b) magnetic polishing [25]

\subsection{Laser}

Laser machining of the cutting edges is viable and possibly cheaper alternative to mechanical cutting edge preparation. It is even possible to achieve better results than with conventional technologies, depending on the type of laser and process parameters. Use of standard marking lasers can be cheaper than use of more expensive high frequency pulse solid state lasers, without significant decrease of cutting edge quality.

One of the important features of the laser beam for cutting edge preparation is Gaussian distribution of the beam's spot diameter, so that there is a transition area between the surface that has been modified by the laser beam and the unaffected area. [27]

Parameters of the laser machining are following:

- Pulse frequency

- Number of ablation layers

- Scanning speed

- Scan overlap factor [28] 


\subsection{Electro-erosion}

Modification of cutting edges using electro erosive method is viable for both high speed steel and solid carbide tools, since both materials are conductive. Due to requirement of conductivity of the material, it is not possible to use this method for tool materials such as ceramics or PCBN. However, for the conductive tool materials, use of this process has advantages compared to mechanical edge preparation methods, as it removes the oxides from the surface layer of the tool, making it more suitable for coating. [29]

Parameters of the process are following:

- voltage,

- discharge current,

- pulse duration,

- pulse interval time [30]

\section{Conclusion}

Various mechanical and thermal methods of edge preparation were reviewed and summarized in the article, along with an overview of their properties and parameters. Purpose of the article was to describe the processes of edge preparation in order to familiarize the reader with them, as well as highlight the importance of cutting edge microgeometry of milling tools, and how they influence tool wear.

Modifying the cutting edge shape can have positive impact not only on the tool life, but also on many other aspects of milling process, such as cutting forces, generated heat and workpiece material surface quality. In extension to these advantages, it can help keeping the machining more economical.

Therefore it can be assumed that the knowledge about the methods of cutting edge preparation is important not just from a technological standpoint, but an economic one as well. Increasing productivity is an ever present goal for every company, and it applies even more so for the tool manufacturers and affiliated fields.

\section{Acknowledgements}

This work was supported by the Scientific Grant Agency of the Slovak Republic under the grant no. 1/0097/17 and the Slovak Research and Development Agency of the Slovak Republic under the Contract no. APVV-16-0057.

\section{References}

Fulemova, J.; Řehoř, J. 2015. Influence of Form Factor oft he Cutting Edge on Tool Life during Finishing Milling. In Procedia Engineering, Vol. 100, 682-688 
Rech, J. Influence of cutting edge preparation on the wear resistance in high speed dry gear hobbing. In Wear. Vol. 261, Issues 5-6, pp. 505-512, September 2006.

Dana, M.; Zetek, M. \& Schorník, V. (2016). Effect of Cutting Edge Geometry on Cutting Tool Life when Drilling Inconel 718, Proceedings of the 26th DAAAM International Symposium, pp.0709-0714, B. Katalinic (Ed.), Published by DAAAM International, ISBN 978-3-902734-07-5, ISSN 1726-9679, Vienna, Austria DOI: 10.2507/26th.daaam.proceedings.098

Vopat, T.; Kuruc, M.; Simna, V.; Zaujec, R. \& Peterka, J. (2017). Cutting Edge Microgeometry and Preparation Methods, Proceedings of the 28th DAAAM International Symposium, pp.0384-0391, B. Katalinic (Ed.), Published by DAAAM International, ISBN 978-3-902734-11-2, ISSN 1726-9679, Vienna, Austria DOI: 10.2507/28th.daaam.proceedings.054

Rodríguez, C.J.C. Cutting edge preparation of precision cutting tools by applying micro-abrasive jet machining and brushing. Kassel University Press GmbH., Kassel 2009.

Hronek, O.; Zetek, M. \& Baksa, T. (2017). The Immersion Depth Influences on Cutting Edge Radius During Drag Finishing, Proceedings of the 28th DAAAM International Symposium, pp.1030-1036, B. Katalinic (Ed.), Published by DAAAM International, ISBN 978-3-902734-11-2, ISSN 1726-9679, Vienna, Austria DOI: 10.2507/28th.daaam.proceedings. 143

Vopat, T.; Kuruc, M.; Simna, V.; Necpal, M.; Buransky, I.; Zaujec, R. \& Peterka, J. (2018). The Influence of Cutting Edge Radius Size on the Tool Life of Cemented Carbide Drills, Proceedings of the 29th DAAAM International Symposium, pp.04210425, B. Katalinic (Ed.), Published by DAAAM International, ISBN 978-3-90273420-4, ISSN 1726-9679, Vienna, Austria DOI: 10.2507/29th.daaam.proceedings.062 Barletta, M.; Gisario, A.; Venettacci, S.; Rubino G. A comparative evaluation of fluidized bed assisted drag finishing and centrifugal disk dry finishing. In Engineering Science and Technology, Vol. 17, pp. 63 -72, 2014.

Vozár, M.; Peterka, J.; Vopát, T.; Pätoprstý, B. Multi-criteria analysis of drag finishing the cutting edges of solid carbide mills. In Manufacturing Technology - Pilsen 2019. 8th International Conference , 5. - 6. 2. 2019, Plzeň. 1. ed. Plzeň : University of West Bohemia in Pilsen, 2019, S. 140-149. ISBN 978-80-261-0829-0.

Pätoprstý, B.; Pokorný, P.; Vopát, T.; Vozár, M.; Šimna, V. Influence of cutting edge preparation conditions on the cutting edge radius and surface roughness. In Manufacturing Technology - Pilsen 2019. 8th International Conference, 5. - 6. 2. 2019, Plzeň. 1. vyd. Plzeň : University of West Bohemia in Pilsen, 2019, S. 86-95. ISBN 978-80-261-0829-0.

OTEC. (2018) Drag finishing products. [Online]. Available from: https://www.otec.de/en/products/mass-finishing/drag-finishing-machines/ 
Fulemova, J.; Janda, Z. 2014. Influence of the Cutting Edge Radius and the Cutting Edge Preparation on Tool Life and Cutting Forces at Inserts with Wiper Geometry. In Procedia Engineering 69, 565 - 573

Baksa, T.; Schornik, V.; Adamek, P. \& Zetek, M. (2016). Machining of Inconel 718 Using Uncoated Cutting Tools With Different Cutting Edge Quality, Proceedings of the 27th DAAAM International Symposium, pp.0441-0446, B. Katalinic (Ed.), Published by DAAAM International, ISBN 978-3-902734-08-2, ISSN 1726-9679, Vienna, Austria DOI: 10.2507/27th.daaam.proceedings.065

Denkena, B.; Köhler, J.; Ventura, C.E.H. Customized cutting edge preparation by means of grinding. In Precision Engineering, Vol. 37, pp. 590- 598, 2013.

Bouzakis, K.-D.; Klocke, F.; Skordaris, G.; Bouzakis, E.; Gerardis, S.; Katirzoglou, G.; Makrimallakis, S. Influence of dry micro-blasting grain quality on wear behaviour of TiAlN coated tools. In Wear, Vol. 271, pp. 783-791, 2011.

Hronek, O. \& Zetek, M. (2017). The Influences of Cutting Edge Radius on Surface Roughness when Milling Nickel Alloy, Proceedings of the 28th DAAAM International Symposium, pp.1037-1043, B. Katalinic (Ed.), Published by DAAAM International, ISBN 978-3-902734-11-2, ISSN 1726-9679, Vienna, Austria DOI: 10.2507/28th.daaam.proceedings. 144

Tanaka, S.; Shirochi, T.; Nishizawa, H.; Metoki, K.; Miura, H.; Hara, H.; Takahashi, T. Micro-blasting effect on fracture resistance of PVD-AlTiN coated cemented carbide cutting tools. In Surface \& Coatings Technology 308 (2016) 337-340

Tönshoff, HK.; Mohlfeld, A. Surface Treatment of Cutting Tool Substrates. In Int. Journal of Machine Tools and Manufacture, Vol. 38, Issues 5-6, pp.469-476, 1998.

Wyen, C.-F. Rounded Cutting Edges and Their Influence in Machining Titanium, PhD-Thesis, ETH Zürich, Zürich, Switzerland, 2011.

Saunders, D. Jet Cutting Technology - Chapter 7: A Study of Brittle Erosion Mechanism Applied to Abrasive Waterjet Processes. In Proceedings of the 10th Int. symposium. Elsevier Science Publisher Ltd., Amsterdam, Netherlands, 1991.

Biermann, D.; Aßmuth, R.; Schuman, S., Rieger, M.; Kuhlenkötter, B. Wet abrasive jet machining to prepare and design the cutting edge micro shape. In Procedia CIRP, Vol. 45, pp. 195 - 198, 2016.

Zhang, S.; Zou, B.; Liu, Y.; Wang, Y.; Huang, C.; Liu Z. Edge passivation and quality of carbide cutting inserts treated by wet micro-abrasive blasting. In The International Journal of Advanced Manufacturing Technology (2018) 96:2307-2318

Gabriel, T. V.; Sattel, S.; Popa, M. S. Application of abrasive sand blasting process in micro geometrical cutting edge optimization. In Technical Gazette, Volume 23, Issue 4, pp. 1171-1176, 2016.

Hronek, O.; Zetek, M. \& Baksa, T. (2018). The Influence of Cutting Edge Radius on Force Load when Milling Inconel 718, Proceedings of the 29th DAAAM International Symposium, pp.0822-0828, B. Katalinic (Ed.), Published by DAAAM International, 
Vozar, M.; Patoprsty, B.; Vopat, T. \& Peterka, J.: Overview of Methods of Cutting ...

ISBN 978-3-902734-20-4, ISSN 1726-9679, Vienna, Austria DOI: 10.2507/29th.daaam.proceedings.119

Cheung, F.Y.; Zhou, Z.F.; Geddam, A.; Li; K.Y. Cutting edge preparation using magnetic polishing and its influence on the performance of high-speed steel drills. In Journal of materials processing technology, Vol. 208, pp. 196-204, 2008.

Yang, L-D.; Wu, K-L.; Yeh, C-C.; Lee, H-M. Study on Precision Polishing Technology Combining Electrophoresis and Magnetic Finishing. International Journal of Materials Science and Applications. 2016; 5(6): 235-240

Denkena, B.; Kramer, N.; Siegel, F.; Kästner, J. Methoden zur Präparation von Zerspanungswerkzeugen: Leistungsoptimierung an der Schneidkanten, VDI-Z Special Werkzeuge, Vol. 8, pp. 24-26, (2007).

Aurich, J. C.; Zimmerman, M.; Leitz, L.The preparation of cutting edges using a marking laser. In Prod. Eng. Res. Devel. (2011) 5:17-24

Zhuyu, L.; Hongyang, W.; Haoyang, S.; Wei, Z. Electrolytic Abrasive Edge Honing of Cemented Carbide Cutting Tools. 2018 IOP Conf. Ser.: Mater. Sci. Eng. 382032052 Chen, Y.; Mahdavian, S. Parametric study into erosion wear in a computer numerical controlled electro-discharge machining process. Wear, 236 (1999), pp. 350-354 